\title{
JEKK
}

\section{Hubungan Paparan Asap dengan Kejadian Infeksi Saluran Pernapasan Akut (ISPA) pada Anak Usia 0-5 Tahun di Wilayah Pertanian Kecamatan Panti Kabupaten Jember}

\author{
Vivi Oktaviana Wulandari", Latifa Aini Susumaningrum*, Tantut Susanto*, Abdul Kholis** \\ *Departemen Keperawatan Komunitas, Keluarga, dan Gerontik, Fakultas Keperawatan \\ Universitas Jember, ${ }^{* *}$ Puskesmas Panti, Dinas Kesehatan, Kabupaten Jember
}

\begin{abstract}
Background: Acute respiratory infections (ARI) in developing countries at the age of under five have a fairly high prevalence, which relates to air pollution at home, such smoke as firewood, cigarette and mosquito coils.

Methods: The purpose of this study was to examine the relationship between smoke exposure of ARI in age child 0-5 year in agricultural area Panti District, Jember Regency. A case control study design was conducted among grup control 120 and case grup 120 of respondent using stratified random sampling. A self administered questionnaire was used to interview indoor air quality. Chi Square test was perform to analyze the relationship between smoke exposure of ARI.

Result: The result identified as exposure to firewood smoke $63.3 \%$, exposure to cigarette smoke $75.8 \%$ and exposure to smoke from mosquito coils $68.3 \%$. There were significantly relationship between firewood $(\chi 2=5.813 ; p$-value $=0.016)$, exposure to cigarette smoke $(\chi 2=9.094 ; \mathrm{p}$-value $=$ $0.004)$, can immediately bring mosquito coils $(\chi 2=4.929$; $p$-value $=0.037)$. Smoke exposure is relationship with ARI in age child 0-5 year.
\end{abstract}

Conclusion : Therefore, efforts to ARI can be prevented by family who maintain air quality at home.

Keywords: ARI; children; firewood smoke; cigarette smoke; mosquito coil smoke

\footnotetext{
*Penulis korespondensi, tantut_s.psik@unej.ac.id
} 


\section{Pendahuluan}

Penyakit infeksi saluran pernapasan akut (ISPA) merupakan salah satu penyebab utama kematian pada balita di dunia. ${ }^{1}$ Tingkat morbiditas dan mortalitas penyakit ini cukup tinggi terutama pada balita di negara berkembang. ${ }^{2}$ The Sidrap Agency memberi peringkat ISPA sebagai urutan pertama di antara sepuluh penyakit paling umum selama lima tahun dari 2011 sampai 2015. ${ }^{3}$ Faktor lingkungan yang menyebabkan ISPA terjadi karena adanya pencemaran udara yang disebabkan aktivitas penghuni rumah salah satunya seperti ada kebiasaan anggota keluarga yang merokok, kebiasaan menggunakan obat nyamuk bakar dan kebiasaan memasak menggunakan kayu bakar. ${ }^{4}$

Sumber asap rokok yang berasal dari dalam ruangan lebih membahayakan dari pada di luar ruangan, karena $60-90 \%$ orang lebih banyak menghabiskan waktunya di dalam rumah. Rumah tangga di Kecamatan Panti terdapat 12.945 warga yang masih memilih memasak menggunakan kayu bakar. ${ }^{5}$ Indonesia sebagai negara tropis yang memiliki Iklim panas dan lembab digemari untuk hidup dan berkembang biak oleh nyamuk, sehingga obat nyamuk bakar menjadi salah satu yang paling banyak digunakan di wilayah pedesaan alasannya karna murah. ${ }^{6}$ Fenomena yang terjadi saat ini keadaan rumah dengan ventilasi yang buruk mengakibatkan akan banyaknya asap yang di hirup oleh balita, sehingga dapat menyebabkan gangguan kesehatan salah satunya terjadinya peningkatan penyakit ISPA pada balita.

Kecamatan Panti Jember merupakan daerah tertinggi angka kejadian ISPA sebanyak 4181 Balita. Peneliti akan berfokus pada balita yang dirumahnya terdapat perokok aktif, menggunakan obat nyamuk bakar dan memasak dengan bahan bakar kayu, faktanya ada dua kelompok umur yang rentan terhadap penyakit ISPA yaitu kelompok usia dibawah 1 tahun sebesar $35 \%$ dan kelompok umur 1-4 Tahun sebesar $42 \% .^{7}$ Hal ini mendasari pentingnya untuk dilakukan kajian penelitian tentang penyakit ISPA di Kecamatan panti terutama pada populasi Balita yang berkaitan dengan penggunaan kayu bakar dalam tatanan rumah tangga.

Penelitian terdahulu yang dilakukan menunjukkan adanya hubungan antara penggunaan kayu bakar dengan kejadian ISPA di Lembang Batu Sura' karna dari 75 responden yang menggunakan kayu bakar untuk memasak 53 responden terdiagnosa ISPA dan 22 responden tidak terdiagnosa ISPA. Berdasarkan kajian tentang karakteristik lingkungan rumah tangga di wilayah pertanian yang menggunakan kayu bakar merokok didalam rumah dan obat nyamuk bakar serta permasalahan ISPA pada kelompok Balita, maka penelitian ini bertujuan untuk menganalisis Hubungan Paparan Asap dengan kejadian ISPA pada Anak usia 0-5 Tahun di wilayah pertanian Kecamatan Panti Jember. ${ }^{8}$

\section{Metode}

Penelitian dengan desain studi case control dengan pendekatan retrospektif di wilayah kerja puskesmas, Kecamatan Panti, Kabupaten Jember, Jawa Timur. Populasi dalam penelitian ini adalah ibu yang memiliki anak usia 0-5 tahun terdiagnosis ISPA dan tidak terdiagnosis ISPA. Besar populasi 4181 setelah dihitung menggunakan stratiefied didapatkan hasil sebanyak 120 kelompok kasus dan 120 kelompok kontrol, besar sampel ditentukan dengan tingkat kepercayaan 95\%, dengan tingkat kemaknaan $\left(\mathrm{Z}_{1-\alpha / 2}=1,96\right)$, tingkat kesalahan absolut $(\mathrm{d}=0,05)$.

Kriteria inklusi kelompok kasus sebagai berikut: 1) Keluarga yang memiliki anak usia 0-5 tahun terdiagnosa ISPA; 2) Keluarga yang mempunyai kebiasaan sehari-hari menggunakan bahan bakar kayu; 3) Terdapat keluarga perokok aktif; 4) Memiliki kebiasaan menggunakan obat nyamuk bakar; 5) Dapur menjadi satu dengan rumah; 6) Keluarga yang menetap di Kecamatan Panti, sedangkan kriteria inklusi kelompok kontrol yang membedakan hanya di poin pertama yaitu keluarga yang memiliki anak usia 0-5 tahun tidak terdiagnosis ISPA. Kriteria ekslusi kelompok kasus dan kelompok kontrol sebagai berikut: 1) Ibu yang memasak menggunakan kayu bakar di luar rumah; 2) balita yang memiliki penyakit kronis seperti (TB paru, 
kanker); 3) keluarga yang tidak bersedia menjadi responden.

Skreening sampel dari 120 kelompok kasus dan 120 kelompok kontrol teridentifikasi dari semua sampel yang masuk dalam kriteria inklusi peneliti. Pengambilan sampel dengan memperhatikan strata (tingkatan) dalam populasi yang terdiri dari 7 Desa di Kecamatan Panti yaitu Kemuning Lor, Glagahwero, Serut, Panti, Pakis, Suci, Kemiri. Berikut penjelasan terkait dengan teknik pengambilan responden dalam penelitian ini dapat dilihat pada Gambar 1 .

4181 populasi penelitian (balita ISPA)

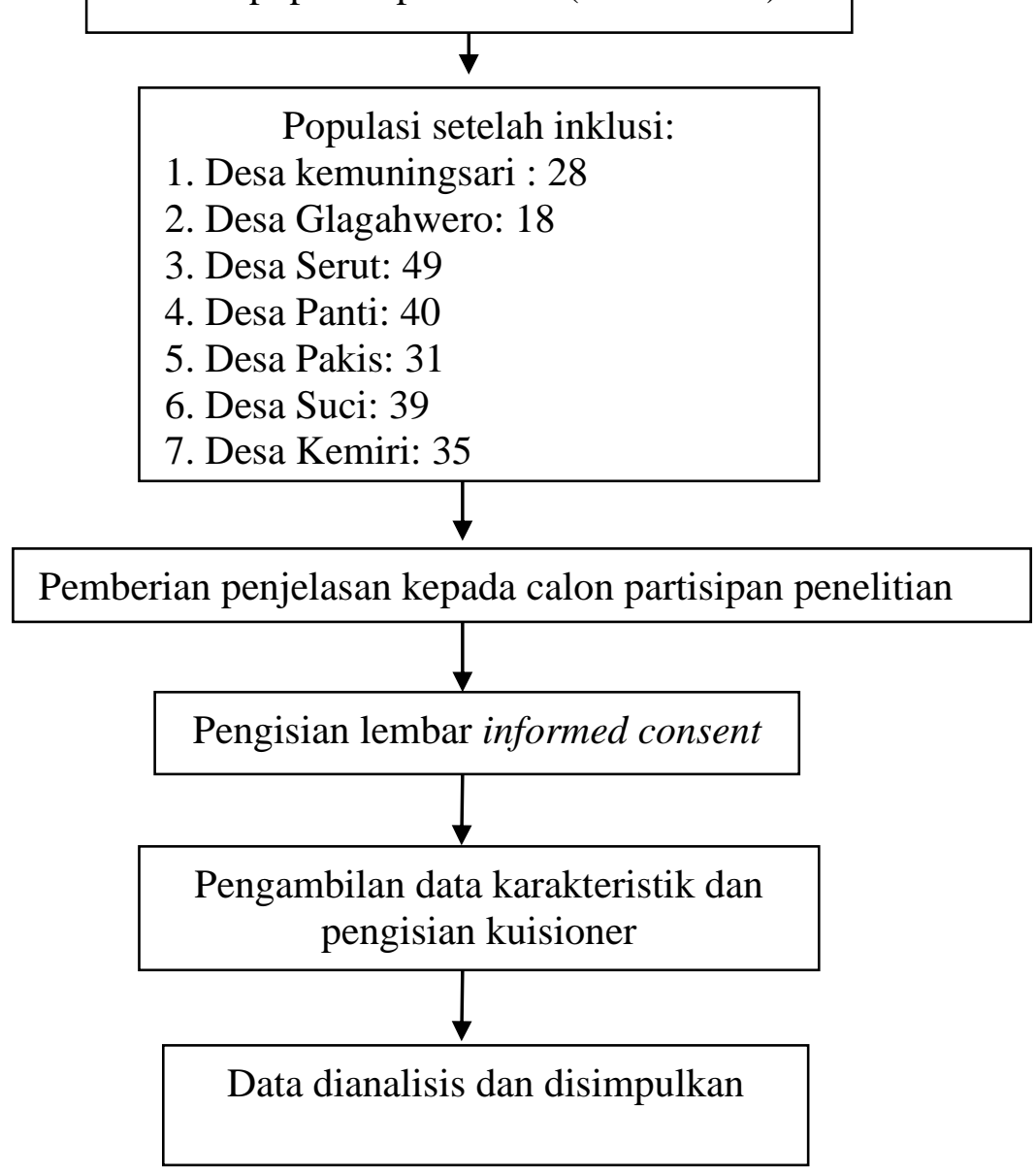

Gambar 1. Teknik Pengambilan Responden

Pengumpulan data dalam penelitian ini menggunakan kuesioner formulir wawancara pemantauan kualitas udara dalam ruang rumah digunakan oleh penelitian Menteri kesehatan RI No 1077/MENKES/PER/V/2011 sebagai pedoman penyehatan udara dalam ruang rumah untuk mengukur paparan asap, sedangkan ISPA dilihat dari data riwayat diagnosa ISPA pada anak dari bulan bulan Januari 2018 - Mei 2019 di Puskesmas Panti.

Kuesioner karakteristik responden yang digunakan berisi data karakteristik ibu meliputi usia, pekerjaan, pendidikan terakhir dan jumlah penghuni rumah, sedangkan anak meliputi jenis kelamin, usia dan riwayat ISPA. Kuesioner pemantauan kualitas udara dalam ruang rumah berisi 8 pertanyaan kepada responden tujuannya untuk mencaritahu kualitas udara di dalam rumah dengan jawaban iya $=1$ dan tidak $=2$. Dari 8 pertanyaan terdapat pertanyaan penggunaan bahan bakar, terdapat perokok aktif di keluarga dan kebiasaan menggunakan obat nyamuk bakar kemudian dilihat hasil Continuity Correction. 
Intrumen ini telah dilakukan uji coba terlebih dahulu untuk mengetahui mutu dari sebuah instrumen. Intrumen ini telah di uji validitas dan uji relibialitas pada keluarga yang memiliki balita ISPA sebesar 10 responden dan balita sehat sebesar 10 responden yang terdiagnosa ISPA di wilayah Puskesmas Panti. Hasil uji validitas berdasarkan item total correlation berkisar 0,556-0,982 ( $\mathrm{r}$ tabel = 0,444) sedangkan uji Reliabilitas untuk kuesioner menggunakan cronbach's alpha di dapatkan hasil 0,966.

Peneliti menjelaskan keterlibatan klien untuk menjadi responden dan tujuan dari penelitian. Peneliti memberikan lembar informed-consent untuk dipahami dan ditandatangani. Selanjutnya peneliti menjelaskan cara mengisi kuesioner kepada ibu lalu memberikan lembar kuesioner untuk diisi. Penelitian ini mendapatkan ijin etik dari Komite Etik Penelitian Kesehatan (KEPK) Fakultas Kedokteran Gigi Universitas Jember dengan Nomor 551/UN25.8/KEPK/DL/2019.

Analisis univariat data numerik karakteristik usia ibu dan jumlah penghuni rumah distribusi frukuensi disajikan dalam bentuk nilai median, minamal, maksimal dan presentil 25-75 menggunakan uji normalitas data menggunakan uji Kolmogorov-Smirnov, sedangkan untuk data kategorik usia, pendidikan terakhir, jumlah penghuni rumah dan lokasi pemukiman serta nama anak, jenis kelamin dan riwayat ISPA distribusi frekuensi menggunakan hasil presentase. Sedangkan analisis bivariat digunakan untuk mengetahui hubungan masing-masing variabel sehingga dapat diketahui ada atau tidak adanya hubungan antara kedua variable dengan menggunakan uji Chi square $(<0,005)$.

\section{Hasil}

Karakteristik Ibu dan Anak ditunjukkan pada Tabel 1 nilai tengah usia ibu 29 tahun dengan mayoritas sebagai ibu rumah tangga $(53,3 \%)$. Terindentifikasi keluarga yang tinggal di daerah pertanian $(97,4 \%)$ dengan jumlah penghuni rumah rata-rata 5 orang dalam satu keluarga dan didapatkan tingkat pendidikan terakhir ibu rata-rata SD $(47,6 \%)$. Jenis kelamin anak mayoritas laki-laki $(55,0 \%)$ dengan rentang usia $0-12$ bulan $(33,3 \%)$, sedangkan riwayat ISPA pada anak didapatkan sesuai dengan sampel penelitian kelompok kasus dan kontrol masing-masing sebanyak $120(50,0 \%)$.

Tabel 1. Karakteristik Ibu dan Anak di Kecamatan Panti (n=240; Oktober 2019)

\section{Karakteristik Ibu}

n $(\%)$

\begin{tabular}{lr}
\hline Usia (tahun) & $29(25-35)$ \\
Md $\left(\mathrm{P}_{25}-\mathrm{P}_{75}\right)$ & \\
\hline Pekerjaan & $6(2,6)$ \\
$\quad$ Buruh tani & $122(53,3)$ \\
Ibu rumah tangga & $101(44,1)$ \\
$\quad$ Wiraswasta & \\
\hline Lokasi Rumah & $223(97,4)$ \\
$\quad$ Pertanian & $1(0,4)$ \\
Industri & $5(2,2)$ \\
Jalan raya & $16(7,0)$ \\
\hline Pendidikan Terakhir & $109(47,6)$ \\
Tidak sekolah & $51(22,3)$ \\
SD & $47(20,5)$ \\
SLTP & $6(2,6)$ \\
SLTA & \\
Perguruan Tinggi & $5(4-6)$ \\
\hline Jumlah Penghuni Rumah & \\
Md (P $\left.25-P_{75}\right)$ & \\
\hline
\end{tabular}




\begin{tabular}{lr}
\hline Karakteristik Anak & n (\%) \\
\hline Jenis kelamin balita & \\
Laki-laki & $132(55,0)$ \\
Perempuan & $108(45,0)$ \\
\hline Usia (Bulan) & \\
$0-12$ & $80(33,3)$ \\
$13-24$ & $49(20,4)$ \\
$25-36$ & $44(18,3)$ \\
$37-47$ & $30(12,5)$ \\
$48-60$ & $37(15,4)$ \\
\hline Riwayat ISPA balita & \\
Terdiagnosa ISPA & $120(50,0)$ \\
Tidak terdiagnosa ISPA & $120(50,0)$ \\
\hline
\end{tabular}

$\mathrm{Md}=$ Median $; \mathrm{P}_{25}-\mathrm{P}_{75}=$ Percentiles ke 25-75; $\mathrm{n}(\%)=$ Jumlah Partisipan (Presentase)

Paparan Asap Terhadap Anak Usia 0-5 > 1 jam sebesar 62,1\%, ibu yang membawa Tahun di Wilayah Pertanian Kecamatan anak ke dapur sebesar 63,8\%. Kondisi dapur Panti Kabupaten Jember

Berdasarkan Tabel 2 dapat dilihat masyarakat di daerah pertanian jenis alat untuk memasak menggunakan tungku/tumang sebesar 48,3\% dengan bahan bakar kayu sebesar 63,3\%. Durasi ibu memasak mayoritas yang tidak terdapat ventilasi sebesar $57,1 \%$, yang mengeluhkan perih pada mata sebesar $48,8 \%$, sedangkan anggota keluarga yang merokok sebesar $75,8 \%$ dan pengguna obat nyamuk bakar sebesar $68,3 \%$.

Tabel 2. Distribusi Pemantauan Kualitas Udara dalam Rumah Setiap Pertanyaan

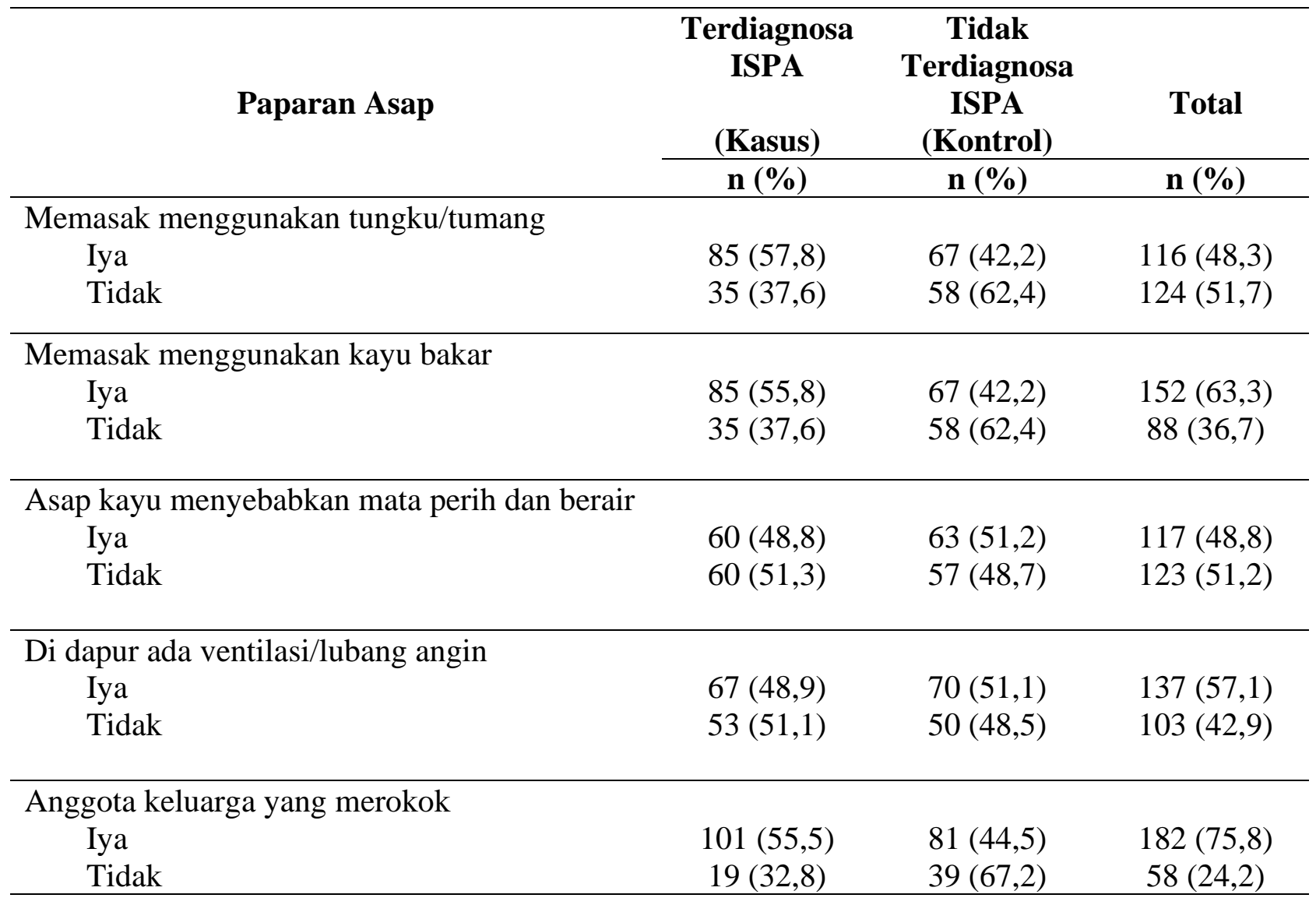




\begin{tabular}{|c|c|c|c|}
\hline \multirow[t]{2}{*}{ Paparan Asap } & $\begin{array}{c}\text { Terdiagnosa } \\
\text { ISPA } \\
\text { (Kasus) }\end{array}$ & $\begin{array}{c}\text { Tidak } \\
\text { Terdiagnosa } \\
\text { ISPA } \\
\text { (Kontrol) }\end{array}$ & Total \\
\hline & n $(\%)$ & n $(\%)$ & n $(\%)$ \\
\hline \multicolumn{4}{|l|}{ Menggunakan obat nyamuk bakar } \\
\hline Iya & $90(54,9)$ & $74(45,1)$ & $164(68,3)$ \\
\hline Tidak & $30(39,5)$ & $46(60,5)$ & $76(31,7)$ \\
\hline \multicolumn{4}{|l|}{ Lama memasak setiap hari } \\
\hline$<1$ jam & $44(50,6)$ & $43(49,4)$ & $87(36,2)$ \\
\hline$>1 \mathrm{jam}$ & $76(49,7)$ & $77(50,3)$ & $153(63,8)$ \\
\hline \multicolumn{4}{|c|}{ Saat memasak membawa balita ke dapur } \\
\hline Iya & $78(52,3)$ & $71(47,7)$ & $149(62,1)$ \\
\hline Tidak & $42(46,2)$ & $49(53,8)$ & $91(37,9)$ \\
\hline
\end{tabular}

Tabel 3 menunjukkan bahwa ada hubungan antara paparan asap kayu bakar $\left(\chi^{2}=\right.$ p-value $=0,004)$ dan asap obat nyamuk bakar $5,185 ; p$-value $=0,023)$, asap rokok $\left(\chi^{2}=8,208\right.$; $\left(\chi^{2}=4,929 ; p\right.$-value $\left.=0,037\right)$ dengan kejadian ISPA pada anak usia 0-5 tahun.

Tabel 3. Distribusi Frekuensi Keterpaparan Anak Usia 0-5 Tahun terhadap Asap Kayu Bakar di Kecamatan Panti Kabupaten Jember $(n=240)$

\begin{tabular}{|c|c|c|c|c|c|c|}
\hline Keterpaparan & $\begin{array}{l}\text { Terdiagnosa } \\
\text { ISPA } \\
\text { (Kasus) }\end{array}$ & $\begin{array}{c}\text { Tidak } \\
\text { Terdiagnosa } \\
\text { ISPA } \\
\text { (Kontrol) }\end{array}$ & Total & $\chi^{2}$ & $p$-value & $\begin{array}{c}\text { OR (CI } \\
95 \%)\end{array}$ \\
\hline & n (\%) & n (\%) & n (\%) & & & \\
\hline $\begin{array}{l}\text { Terpapar kayu } \\
\text { bakar }\end{array}$ & $85(70,8)$ & $67(55,8)$ & $152(63,3)$ & 5,185 & 0,023 & $\begin{array}{c}1,921 \\
1,127-3,276 \\
\end{array}$ \\
\hline $\begin{array}{l}\text { Tidak terpapar } \\
\text { asap kayu bakar }\end{array}$ & $35(29,2)$ & $53(44,2)$ & $88(36,7)$ & & & \\
\hline $\begin{array}{l}\text { Terpapar asap } \\
\text { rokok }\end{array}$ & $101(84,2)$ & $81(75,8)$ & $182(75,8)$ & 8,208 & 0,004 & $\begin{array}{c}2,559 \\
1,375-4,765 \\
\end{array}$ \\
\hline $\begin{array}{l}\text { Tidak terpapar } \\
\text { asap rokok }\end{array}$ & $19(15,8)$ & $39(32,5)$ & $58(24,2)$ & & & \\
\hline $\begin{array}{l}\text { Terpapar obat } \\
\text { nyamuk bakar }\end{array}$ & $90(75)$ & $74(61,7)$ & $164(68,3)$ & 4,929 & 0,037 & $\begin{array}{c}1,865 \\
1,072-3,243\end{array}$ \\
\hline $\begin{array}{ll}\text { Tidak } & \text { terpapar } \\
\text { obat } & \text { nyamuk } \\
\text { bakar } & \end{array}$ & $30(25)$ & $46(38,3)$ & $76(31,7)$ & & & \\
\hline
\end{tabular}




\section{Pembahasan}

Berdasarkan lokasi penelitian didaerah pertanian, mengingat bahwa masih banyak hutan yang menjadi sumber adanya kayu untuk bisa di manfaatkan menjadi bahan bakar memasak. Hasil dari penelitian teridentifikasi yang menggunakan tungku/tumang sebesar $57,8 \%$. Ibu yang membawa anak dalam melakukan aktifitas memasak di dapur sebesar $62,1 \%$ dengan durasi memasak lebih dari 1 jam sebesar 63,8\%. Kondisi dapur yang tidak terdapat ventilasi di dapur terdapat $42,9 \%$, yang mana semua hasil tersebut terbukti terdiagnosa ISPA. Penelitian ini selaras dengan penelitian. ${ }^{9}$ Salah satu faktor terjadinya ISPA karena anak sering dibawa ke dapur ketika memasak. Oleh karena itu, hal ini perlu diperhatikan oleh ibu untuk tidak melibatkan anak dalam aktifitas memasak didalam dapur untuk menghindari risiko buruknya kesehatan anak. Paparan polusi yang terus menerus bisa meningkatkan risiko lebih terhadap kejadian ISPA pada anak. ${ }^{10}$ Polusi dipengaruhi oleh kondisi fisik rumah yang belum memenuhi syarat seperti tidak adanya cerobong asap atau ventilasi di dapur yang tidak memadai hal tersebut memperburuk kualitas udara dalam rumah. ${ }^{11}$ Lebih lanjut, pentingnya ada ventilasi atau cerobong asap di dapur, hal tersebut untuk memudahkan asap tidak tertimbun lama di dalam ruangan sehingga meminimalisir polusi yang dihirup.

Asap rokok memiliki dampak buruk terhadap kesehatan, terutama risiko masalah pernafasan yang menjadi penyebab ketika anak dekat dengan perokok. Penelitian ini sejalan dengan. ${ }^{12}$ mengatakan semakin tinggi paparan asap rokok maka risiko anak terinvasi ISPA juga semakin tinggi. Oleh karena itu, alangkah baiknya perokok aktif tidak membiasakan dirinya untuk merokok didalam rumah karena hal itu menjadi salah satu faktor internal perilaku buruk yang mengakibatkan anak mudah terpapar asap rokok sehingga mengakibatkan ISPA. Kebiasaan keluarga merokok didalam rumah bisa menjadi salah satu penyumbang kualitas udara menjadi buruk sehingga membahayakan kesehatan anak. ${ }^{13}$ Lebih lanjut, Semakin keluarga membiasakan perilaku merokok didalam rumah, maka semakin menimbulkan masalah kesehatan yang lebih serius. Untuk itu perlu membentuk perilaku kebiasaan-kebiasaan baik didalam rumah untuk menciptakan lingkungan yang sehat terhadap anak.

Hasil pada penelitian terdapat $75 \%$ anak terdiagnosa ISPA dengan keluarga yang memiliki kebiasaan sehari-hari menggunakan obat nyamuk bakar. Penelitian ini selaras dengan penelitian. ${ }^{14}$ bahwa obat nyamuk bakar salah satu penyebab kejadian ISPA. Obat nyamuk bakar memiliki kandungan yang lebih berbahaya dibanding asap kayu bakar dan asap rokok, hal tersebut karena asap obat nyamuk di desain sebagai racun pembunuh nyamuk sehingga asap obat nyamuk bakar sama halnya 75-137 batang rokok, maka asap yang sering dihirup memiliki zat-zat yang lebih berbahaya. ${ }^{15}$ Oleh karena itu, paparan asap obat nyamuk perlu diperhatikan karena bahkan lebih berbahaya dibanding paparan asap kayu bakar dan asap rokok. Hal ini perlu kesadaan dari keluarga untuk menghindari penggunaan obat nyamuk bakar dalam mengusir nyamuk didalam rumah.

\section{Kesimpulan}

Berdasarkan hasil penelitian yang dapat disimpulkan terdapat hubungan paparan asap kayu bakar, asap rokok dan obat nyamuk bakar dengan kejadian ISPA pada anak usia 0-5 tahun. Paparan asap rokok yang memiliki risiko paling tinggi yaitu sebesar 2,559 kali pada keluarga yang terdapat perokok aktif.

\section{Daftar Pustaka}

1. Mahendra 2019. Relationship between household physical condition with the incedence of ari on todler at surabaya. Jurnal Epidemiologi. 6(3), pp. 227.

2. Ahmad, H. Wulan. R. A., Zakianis., Azizah, N. F., dan Ashar, Y. K. 2018. The determinant factors of acute respiratory infections ( ARI ) among housewives in allakuang village, south sulawesi, indonesia. KnE Life Sciences. 502-512.

3. Solomon. 2018. Prevalence and risk factors of acute respiratory infection 
among under fives in rural communities of Ekiti State. Nigeria: Global Journal of Medicine and Public Health. 7(1), pp. 112.

4. Sofia. 2017. Faktor risiko lingkungan dengan kejadian ispa pada kabupaten aceh besar. Jurnal Action: Aceh Nutrition Journal. 2(1), pp. 43-50.

5. Badan Pusat Statistik. 2017. Kecamatan Panti dalam Angka tahun 2017. Kecamatan Panti: BPS Jawa Timur.

6. Hogarh, J., N. Agyei, P., A., dan Danso, K., O. 2016. Application of mosquito repellent coils and associated self-reported health issues in Ghana. Malaria Journal. 15:61.

7. Kementrian Kesehatan Republik Indonesia .2018. Laporan Nasional Riskesdas 2018. http://www.depkes.go.id/

8. Layuk. 2012. Faktor yang berhubungan dengan kejadian ispa pada balita di lembang batu sura. Jurnal FKM Universitas Hasanuddin: Makassar. pp. 112.

9. Ashwani, K. Kalosona, P. 2018. Effect of indoor air pollution on acute respiratory infection among children in india. Social and Natural Sciences Journal. Vol 10(2), pp 1-9.

10. Nuryati, E. (2018). Faktor determinan ispa pada daerah home industri (Determinant Factor Acute Respiratory Infection Among Industrian Home). Jurnal Ilmiah Kesehatan. Vol 7(1) Hal. 27-31.
11. Peraturan Menteri Kesehatan Republik Indonesia Nomor 1077/Menkes/Per/V/2011 Tentang "Pedoman Penyehatan Udara Dalam Ruang Rumah”. http://hukor.kemkes.go.id/uploads/produk_ hukum/PMK\%20No.\%201077\%20ttg\%20 Pedoman\%20Penyehatan\%20Udara\%20D alam\%20Ruang\%20Rumah.pdf

12. Sahroni, R., Z dan Tantut, S. 2012. Hubungan kebiasaan merokok anggota keluarga dengan kejadian ispa pada balita di puskesmas ajung kabupaten jember. Skripsi. Jember: Program studi ilmu keperawatan.

13. Hermawati, B. Indarjo, $\mathrm{S}$ dan Sukendra., M. 2019. Relationship of exposure of air pollution in house with occurrence of acute respiratori infections in children under five at Puskesmas Malimongan Baru in 2016. Advance in Social Science, Education anda Humanisties Research. pp362.

14. Sofia. 2017. Faktor risiko lingkungan dengan kejadian ispa pada kabupaten aceh besar. Jurnal Action: Aceh Nutrition Journal. 2(1), pp. 43-50.

15. Zhang, J. Jiang, Z. Tong, J. Wang, Z. Han, Z., dan Zhang, J., J. 2010. Using charcoal as base material reduces mosquito coil emissions of toxins. Indoor Air. 20 (2): 176-184. 